\title{
Umoření listin: ojedinělé řízení s dalekosáhlým dopadem
}

\section{Amortization of Documents: Infrequent Procedure with Far-reaching Impact}

\author{
Ondřej Placzek* , Roman Šafár $\check{r}^{* *}$
}

\begin{abstract}
Abstrakt
Tento článek zkoumá vybrané problematické aspekty soudobé úpravy rízeni o umoreni listin, popisuje jejich praktické projevy a navrhuje možná řešení. Autoř se zaméruji zejména na dopad presunu úpravy

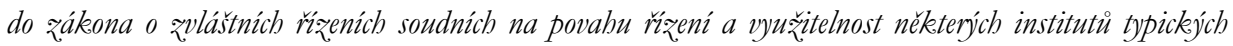
pro sporné rízení, okrub účastniku rízení, podminky umoritelnosti listin a praktické dopady výsledného usneseni o umoreni listiny.
\end{abstract}

\section{Klíčová slova}

Umoreni listin; povaha řzení; cenné papiry; povaha rízeni; navrhovatel; kupóny; edikt; účinky umoření.

\begin{abstract}
This article examines selected problematic aspects of the contemporary regulation of amortization of documents, describes their practical effects and suggests possible solutions. The authors mainly focus on the impact of the transfer of the proceeding's regulation to the Act on Special Judicial Proceedings on the character of the proceeding and usability of certain institutes typical for contradictory proceedings. The authors further focus on the participants of the proceeding, requirements imposed on the amortized documents and practical impacts of the final ruling act.
\end{abstract}

\section{Keywords}

Amortization of Documents; Commercial Papers; Character of Proceeding; Instagator; Coupons; Edict; Effects of Amortization.

\section{Úvod}

Řízení o umoření listin ${ }^{1}$ je jedním $\mathrm{z}$ mnoha řízení, která byla vyňata ze zákona č. 99/1963 Sb., občanský soudní řád, ve znění pozdějších předpisů, a prèemístěna do zákona č. 292/2013 Sb., o zvláštních řízeních soudních, ve znění pozdějších předpisů. Právní úprava s účinností od 1. 1. 2014 se však od té „předrekodifikační“ liší pouze

* Mgr. Ondřej Placzek, asistent soudce, Nejvyšší soud, Brno / Legal Assistant, Supreme Court of the Czech Republic, Brno, Czech Republic / E-mail: ondrej.placzek@gmail.com / ORCID: 0000-0002-4392-3791

** Mgr. Bc. Roman Šafář, doktorand, Katedra obchodního práva, Právnická fakulta, Masarykova univerzita, Brno / Ph.D. student, Department of Commercial Law, Faculty of Law, Masaryk University, Brno, Czech Republic / E-mail: romansafar93@gmail.com / ORCID: 0000-0003-3389-8032

1 V textu budeme používat jak zákonný pojem ,řízení o umoření listiny“, tak i pojmy „umořovací řízeni““, „amortizace“ a „amortizační řízení", a to zaměnitelně. 
v na první pohled nepatrných nuancích, ${ }^{2}$ které však mohou mít za následek i neúspěch v podobě nevydání kýženého usnesení o umoření listiny. Řízení o umoření listin je, jako ostatně každé soudní řízení, způsobilé citelně zasáhnout do právních i osobních poměrů a vztahů účastníků řízení i jejich blízkých osob. Považujeme proto za nutné objasnit některé jeho problematické aspekty.

Účelem řízení je obnovit účinky ztracené, zničené nebo odcizené listiny. Samotný proces umoření listin ,je procesem, jehož koncepce poskytuje primérenou ochranu prèd zneužitím umořeni listiny, jež by vyústilo v následný výkon práv spjatých s umořenou listinou osobou, které takové právo nenáleží. "3 Ochrana osoby z listiny oprávněné je zajištěna znemožněním výkonu práv spojených s umořenou listinou a jejím nahrazením soudním rozhodnutím.

Jak už jsme zmínili, otázka zdánlivě výlučně teoretická může významně ovlivnit výsledek řízení samotného. Konkrétně se jedná o otázku povahy a místa umořovacího řízení v systému jednotlivých civilních řízení. Budeme rozlišovat zejména mezi dvěma základními „sběrnými“" skupinami - civilním řízením sporným a civilním řízením nesporným a na několika základních charakteristických znacích se pokusíme určit, v čem se umořovací řízení liší od nesporných řízení a v čem se naopak podobá řízením sporným.

Dále se budeme zabývat účastníky řízení a s tím související otázkou, kdo je oprávněn podat návrh na umoření řízení. Odpověd’ není zcela jednoznačná. Je však nutné mít postaveno najisto, kdo bude $\mathrm{v}$ pozici účastníka řízení, nebot' i vyřešení této otázky může v konkrétním řízení zcela zásadně ovlivnit, zda soudní rozhodnutí bude pro navrhovatele kladné, nebo zda soud návrh zamítne. ${ }^{4}$

Následně budeme zkoumat i druhou významnou podmínku řízení, kterou je umořitelnost listiny, jejíž umoření je navrhováno. Pokud by totiž listina umořitelná nebyla, výsledkem bude zamítavé rozhodnutí soudu, které by v praxi nic nevyřešilo. Z důvodu důležitosti této podmínky se budeme zabývat též listinami, které nemohou být objektem umoření v daném řízení. Zákonodárce sice stanovil taxativní výčet neumořitelných listin, vedle toho však uvádí, že v řízení o umoření listiny nelze umořit listiny, které je oprávněna dle zákona umořit emitující právnická osoba. Které listiny to jsou? To je další z dílčích otázek, na které se v článku pokusíme nalézt odpověd’.

2 SVOBODA, Karel. Otazníky v řízení o umoření listiny. Jurisprudence, Praha: Wolters Kluwer Česká republika, 2014, č. 6, s. 40-44.

3 CHALUPA, Radim. Díl 2 Řízení o umoření listin. In: LAVICKÝ, Petr a kol. Zákon o zuláštních ř́zeních soudních. Řizeni nesporné. Praktický komentár. Praha: Wolters Kluwer Česká republika, 2015, s. 551.

4 SEDLÁK, Viktor a Alena NOVOTNÁ. \ 304 Předmět řízení. In: JIRSA, Jaromír, Daniela KOVÁŘOVÁ a kol. Občanské soudni ř́zení. Soudcouský komentár. Kniba III. Zvlástni rízeni soudní. 3. vyd. Praha: Wolters Kluwer Česká republika, 2019, 1136 s. 
Poté, co vyjasníme základní podmínky umořovacího řízení, ${ }^{5}$ svou pozornost zaměříme na průběh řízení. Konkrétně se zaměříme na otázky, jež se týkají prvního procesního rozhodnutí soudu. Jde o tzv. edikt, tedy usnesení, jímž se soud v zákonem stanovené lhůtě snaží ověřit, zda umořovaná listina neexistuje v podobě, která vylučuje její amortizaci, a př́ípadně další informace o dané listině. Skutečnosti, které se soud v ediktní lhůtě dozví, jsou důležité pro další průběh řízení. Nebude-li řízení zastaveno nebo nebude-li návrh na umoření zamítnut (a bude-li podán navrhovatelem opětovný návrh), spěje řízení k vydání meritorního rozhodnutí, kterým je usnesení o umoření amortizované listiny. V článku se též budeme zabývat účinky tohoto konečného usnesení.

\section{Sporně nesporný charakter umořovacího řízení}

Ř́zení o umoření listiny je upraveno v ustanoveních \ 303 až \ 315 zákona č. 292/2013 Sb., o zvláštních řízeních soudních, ve znění pozdějších předpisů (dále jen „ZŽR“"). Před nabytím účinnosti ZŘS bylo amortizační řízení upraveno zákonem č. 99/1963 Sb., občanský soudní řád, ve znění pozdějších předpisů (dále jen „OSŘ`). ${ }^{6}$ Zdá se, že zákonodárce zvolil cestu opačnou než u hmotného práva. Zatímco občanské právo hmotné rekodifikoval, nebo se o to alespoň pokusil, civilní právo procesní bylo spíše dekodifikováno, nebot' zvláštní civilní řízení, jimiž jsou taxativně vymezená řízení v ZŘS, byla vyčleněna z OSŘ do zvláštního zákona. Ačkoli podrobná analýza vztahu těchto dvou právních předpisů upravujících civilní řízení není předmětem tohoto článku, ${ }^{7}$ považujeme za důležité nalézt odpověd’ na otázku charakteru umořovacího řízení z pohledu zásad civilního práva procesního. Z těch totiž následně vyplývají práva a povinnosti procesních stran v rrízení o umoření listiny.

Základní teoretickou otázkou s praktickými dopady je, zda lze na řízení o umoření listiny nahlížet jako na řízení ryze nesporné, ryze sporné, nebo jako na kombinaci obou s převažujícími prvky jednoho z nich. S tím ještě souvisí problematická otázka, jestli existují pouze civilní rízení sporná a nesporná, nebo zda jsou vedle této dvojice též řízení smíšená ${ }^{8}$.

5 Obecnými podmínkami rrízení a jejich zkoumáním dle $\ 103$ a násl. OSŘ se nebudeme v tomto textu zabývat.

6 Konkrétně v ustanoveních $\ 185 \mathrm{i}$ až $\ 185 \mathrm{~s}$.

7 Srov. ustanovení $\mathbb{} 1$ odst. 3 a 4 ZŘS. Blíže k této problematice např. KORBEL, František a Dana PRUDÍKOVÁ. \1 Úvodní ustanovení. In: JIRSA, Jaromír, Daniela KOVÁŘOVÁ a kol. Občanské soudní ř̌zení. Soudcovský komentár. Kniba III. Zvlástní rǐzeni soudni. 3. vyd. Praha: Wolters Kluwer Česká republika, 2019, 1136 s.; nebo též LEVÝ, Jiří. \} 1 \text { [Úvodní ustanovení]. In: SVOBODA, Karel, Šárka TLÁŠKOVÁ } a kol. Zákon o zulástnich rízeních soudních. 1. vyd. Praha: Nakladatelství C. H. Beck, 2015, s. 1-2; anebo JURÁŠ, Marek. Působnost civilněprocesních předpisů a príslušnost soudů po 1. 1. 2014. Práuní roz̧hledy, Praha: Nakladatelství C. H. Beck, 2014, č. 3, s. 88-94.

8 Podotýkáme, že pojem ,řízení smíšená“ používáme pro účely tohoto textu, abychom odlišili jednotlivé druhy rízení. Řízením smišseným rozumíme takové rízení, ve kterém se projevují v různé míre prvky řízení sporného i nesporného. 
První názor zastává zejména Petr Lavický, který uvádí, že „, [v] z̧hledem k tomu, že je prakticky nemožné najit společné znaky v̌̌ech drubu nesporných rízení, je zrejejmè vhodnèjsí pokusit se vymezit rìzeni sporné. Tento postup ostatně odpovidá tomu, že - oproti predstavě tvưrců zákona o zvlástnich rízenich soudnich - je řżeni bud’sporné, nebo nesporné, a treti možnosti neni. "9 Petr Lavický a jím citovaní autoři vychází z předpokladu, že civilní řízení nesporné je protikladem rúzení sporného. ${ }^{10}$ Jinými slovy, každé rúzení, které nesplňuje definici civilního řízení sporného, je řazeno mezi ř́izení nesporné.

Proti tomu stojí názor Františka Korbela a Dany Prudíkové, kteří tvrdí, že do Ž̌S byla zahrnuta „i úprava dalšich zvlástnich rizeneni, která byla dosud soucásti občanského soudního rádu a s rekodifikaci soukromého práva prímo nesouvisela (napr. řrzeni o úschovách, řżeni o umořeni listin) "11 Navíc tito autoři vycházejí též z geneze označení zákona, z níž dovozují úmysl zákonodárce. Uvádějí, že původní pracovní název ZŘS byl „zákon o nesporném řízení soudním“, který byl však v průběhu příprav zákona změněn na ,zákon o zvláštních řízeních soudních“, „aby se predkladatelé vyhnuli výbradě, že neobsabuje pouze tradični ,nespory", ale v̌̌echna ř́zeni se specifickou procesni úpravou. "12. Stejný dovozuje i Alena Winterová, která tvrdí,

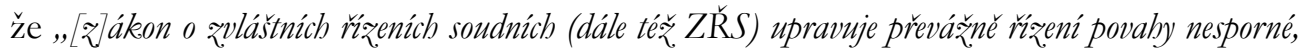
avšak budou se jimi rúdit též nékteré véci jiné, které nejsou typickými ,nespory' a kvili nimž byl zvolen název zákona o, zvláštnich řrzeních! "13 I z úmyslu zákonodárce lze tedy dovodit, že v ZŘS jsou upravena řízení zvláštní, která zahrnují jak řízení nesporná, tak také řízení smíšená.

$\mathrm{V}$ prvé řadě je nutno zohlednit, podle jakých kritérií se dělení civilního procesního práva provádí. Tradičně se postupuje dle účelu řízení, tedy že účelem řízení sporného je reparace (náprava právní sféry, do které bylo zasaženo) a účelem nesporného řízení je prevence (předcházení porušení práva do budoucna). Další kritéria pro určení spornosti řízení jsou povaha soudního rozhodnutí (přičemž typicky v řízeních sporných soudy vydávají deklaratorní rozhodnutí, v řízení nesporných naopak rozhodnutí konstitutivnî), způsob zahájení řízení (sporná řízení jsou zahajována výlučně na návrh, kdežto v případě řízení nesporných soud zahajuje i z úřední povinnosti), či zásady ovládající daný druh řízení (pro řízení sporná jsou typické např̀. zásady dispoziční a projednací, pro řízení nesporná zase např. zásady oficiality a vyšetřovacî).

9 LAVICKÝ, Petr. In: LAVICKÝ, Petr a kol. Zákon o zulástnich rízeních soudních. Řizeni nesporné. Praktický komentár. 1. vyd. Praha: Wolters Kluwer Česká republika, 2015, s. 1-4.

10 Je však nutné doplnit, že Petr Lavický považuje jednoznačné vymezení sporného a nesporného řízení za problematické zejména z toho důvodu, že zákonodárce stále do kategorie nesporných řízení doplňuje další rízení, která s původními „nespory“ nesouvisejí. Srov. LAVICKÝ, Petr. In: LAVICKÝ, Petr a kol. Zákon o zulástních ř̈zenich soudních. Řizeni nesporné. Praktický komentár. 1. vyd. Praha: Wolters Kluwer Česká republika, 2015, s. 1-4.

11 KORBEL, František a Dana PRUDÍKOVÁ. \1 Úvodní ustanovení. In: JIRSA, Jaromír, Daniela KOVÁŘOVÁ a kol. Občanské soudni rízení. Soudcovský komentár. Kniha III. Zvlástni rízeni soudní. 3. vyd. Praha: Wolters Kluwer Česká republika, 2019, 1136 s.

12 Ibid.

13 WINTEROVÁ, Alena, Anna MACKOVÁ a kol. Civilní právo procesní: Díl první: rízení nalézací. 9. aktualizované vyd. Praha: Leges, 2018, s. 359. 
Umořovací řízení se zahajuje výlučně na návrh a jeho účelem je reparace (náhrada ztracené či zničené listiny), výše uvedená kritéria tak poukazují na spornou povahu amortizačního rrízení. Spornosti řízení nasvědčují i zásady, které je ovládají: ustanovení \312 ZŘS vylučuje zásadu vyšetřovací; soud je tak omezen na skutečnosti, jež jsou tvrzeny účastníky řízení. To je typickým projevem zásady projednací, kterou je ovládána většina civilních řízení sporných. Uplatní se rovněž (pro sporná řízení typická) koncentrace ř́izení a zásada neúplné apelace. ${ }^{14}$ Účastníci amortizačního řízení tak nemohou tvrdit novoty, které neuplatnili již v řízení před soudem I. stupně, ledaže by bylo prrípustné uplatnit některou z výjimek stanovených v \205a OŠ̌.

Ke sporné povaze rrízení o umoření listiny se rovněž kloní Karel Svoboda. ${ }^{15}$ Dokládá to zejména na př́kladu ustanovení \312 Ž̌S, které vylučuje aplikaci některých ustanovení z obecné části ZŘS. Soud totiž (vzhledem k vyloučení aplikace ustanovení \17 Ž̌S) může vést přípravné jednání dle $\int 114$ c OSŘ, což je jedním z typických rysů civilního řízení sporného. Nedostaví-li se na přípravné řízení žalobce, ${ }^{16}$ soud po splnění dalších podmínek stanovených v \ 114c odst. 7 OSŘ řízení zastaví. ${ }^{17} \mathrm{~V}$ případě nedostavení se dlužníka $z$ umořované listiny je však vyloučena možnost soudu vydat rozsudek pro uznání, nebot' ustanovení \25 odst. 2 ZŘS, které vydání rozsudku pro uznání či pro zmeškání vylučuje, je na úpravu amortizačního řízení aplikovatelné. ${ }^{18}$ Ostatně by ani nedávalo smysl, pokud by byla osoba $z$ umořované listiny povinná sankcionována za nedostavení se k jednání, nebot' v některých př́padech je tato soudu na začátku řízení neznámá a není proto účastnicí řízení.

Ukázali jsme, že v úpravě ř́zení o umoření listiny lze nalézt výrazné prvky sporného řízení. Ty podle nás vylučují jeho celkovou nespornost. Přesto však nelze amortizační řízení označit za zcela sporné. Hlavním argumentem v neprospěch spornosti je argument účastníků řízení: při zahájení rrízení zde není žádný subjekt, který by byl automaticky v kontradiktorním postavení $\mathrm{k}$ navrhovateli, a k účastenství takovéhoto „oponenta“" navrhovateli v mnoha př́padech ${ }^{19}$ nemusí dojít vưbec.

Jestliže řízení o umoření listin nelze jednoznačně označit jako rrízení sporné či pod řízení nesporné, nezbývá nám než odmítnout tuto dichotomii ${ }^{20}$ a uzavř́it, že amortizační řízení má povahu smíšenou. Při zahájení řízení a vyhlášení ediktu převažují prvky

14 V důsledku vyloučení aplikace ustanovení \28 ZǨS (srov. \312 ZǨS).

15 SVOBODA, Karel. Otazníky v řízení o umoření listiny. Jurisprudence, Praha: Wolters Kluwer Česká republika, 2014, č. 6, s. 40-44.

$16 \mathrm{~V}$ ř́zení o umoření listiny navrhovatel.

17 Dikce zákona, ve které je použito slova „zastavi“, nikoli „může zastavit“, naznačuje, že se jedná o povinnost soudu rrízení o umoření listiny zastavit. Není tedy na uvážení soudu, zda rrízení zastaví, či nikoli.

18 Srov. ustanovení $\$ 312$ ZŘS.

19 Zejm. pokud nikdo neuplatní námitky proti umoření či prrihlášku listiny.

20 Srov. marg. č. 9. 
řízení nesporného, vstoupí-li však do řízení „kontradiktorní“ subjekt (nejčastěji osoba přihlašující listinu či uplatňující námitky proti umořenî), dochází k aktivaci prvků a zásad typických pro řízení sporná.

\section{Věcně a místně příslušný soud}

$\mathrm{K}$ rozhodnutí o umoření listiny jsou podle $\int 3$ odst. 1 Ž̌S věcně příslušné okresní (obvodnî) soudy. Jako místně příslušný uvádí \303 odst. 1 ZŘS obecný soud navrhovatele, a nenachází-li se tento soud v České republice, pak soud, v jehož obvodu je platební místo listiny. Pokud je ovšem výstavcem umořované listiny banka, podle odst. 2 citovaného ustanovení je místně př́slušný soud, v jehož obvodu má tato banka sídlo. Toto obligatorní pravidlo pro místní příslušnost je pro nás překvapivé, protože si nejsme vědomi žádného důvodu pro jeho existenci. Důvodová zpráva k zákonu č. 263/1992 Sb., jímž bylo předmětné pravidlo zavedeno, v tomto ohledu mlčí. Mưžeme se tak pouze domnívat, že zákonodárce inspirovalo znění \ 3 odst. 4 zákona č. 250/1934 Sb. z. a n., o umorování listin. Toto ustanovení však upravovalo pouze amortizaci listin, jejichž výstavcem byla tehdejší centrální banka. Vztažení podobné výjimky na listiny vystavené komerčními bankami je tak podle nás zarážející a neopodostatněné.

Pokud pro konkrétní věc nelze určit místní příslušnost podle pravidel nabízených \ 303 ZŘS, je nutno postupovat podle \11 odst. 3 OŠ̌ a navrhnout, aby místně př́islušný soud určil Nejvyšší soud. V minulosti Jiří Levý uváděl, ${ }^{21}$ že nedostatek místní příslušnosti podle Ž̌S znamená rovněž nedostatek pravomoci českých soudů, nebot' není naplněna podmínka \ 6 odst. 1 zákona č. 91/2012 Sb., o mezinárodním právu soukromém, ve znění pozdějších předpisů (dále jen „ZMPS“). Tento názor však již neobstojí, nebot' Nejvyšší soud jednoznačně potvrdil, že zakládá-li \ 81 ZMPS zakládá pravomoc českých soudů $\mathrm{k}$ umoření listin vystavených $\mathrm{v}$ zahraničí, pokud má jejich amortizace v České republice způsobit právní následky, tím spíše musí být pravomoc českých soudů dána ve věcech umoření všech listin vystavených v České republice, u nichž lze naplnění podmínky „způsobení účinků na území České republiky“ předpokládat. ${ }^{22}$ Jako kritérium pro výběr místně příslušného okresního (obvodního) soudu mưže posloužit např. sídlo (nebankovního) emitenta listiny nebo místo, kde k její zničení či ztrátě došlo.

\section{Nejasná otázka okruhu účastníků řízení}

Umořovací řízení je výlučně návrhové. Otázkou však je, kdo může být iniciátorem amortizačního ř́zení, jinými slovy, jaké podmínky musejí být splněny k tomu, aby se někdo stal navrhovatelem. V každém soudním řízení je nutné zkoumat podmínky řízení. ${ }^{23}$ Jednou

21 LEVÝ, Jiří. In: SVOBODA, Karel a kol. Zákon o quláśtních ř́zeních soudních. Komentár. 1. vyd. Praha: C. H. Beck, 2015, s. 586.

22 K tomu srov. usnesení Nejvyššího soudu ze dne 28. 8. 2019, sp. zn. 30 Nd 422/2018.

23 Srov. ustanovení \ 103 a násl. OSŘ. 
z nich je zkoumání podmínek, které se týkají účastníků řízení. Konkrétně soud zkoumá, zda má osoba navrhovatele a ostatní účastníci způsobilost být účastníkem řízení (dle \19 OSŘ) a zda má procesní způsobilost (\20 OSŘ), pop̌r. je-li platně zastoupen (dle \ 22 a násl. OSŘ) ${ }^{24} \mathrm{~V}$ obecné rovině účastenství se totiž můžeme setkat s různými problémy. Jeden z nich je, jak má soud postupovat, podá-li návrh osoba, která je omezena ve svéprávnosti, přičemž by byla omezená i v záležitosti podání návrhu na umoření listiny ${ }^{25}$. Pokud by byla tato osoba řádně zastoupena opatrovníkem, který bude mít oprávnění osobu navrhovatele $\mathrm{v}$ záležitosti podání návrhu na amortizaci listiny zastupovat, neměl by být problém pokračovat v řízení. Pokud by však návrh podala osoba omezená ve svéprávnosti (omezení by se vztahovalo i na podání návrhu na umoření listiny), bylo by patrně zapotřebí dodatečného souhlasu opatrovníka dle \65 odst. 2 zákona č. 89/2012 Sb., občanský zákoník, ve znění pozdějších předpisů (dále jen „OZ“), př́ípadně by byl osobě omezené ve svéprávnosti jmenován tzv. opatrovník pro řízení dle $\int 29$ odst. 4 OSŘ, který by za navrhovatele v řízení jednal. Osoba s omezenou svéprávností však může podat samostatně takový návrh, tedy má procesní způsobilost v takových jednáních, kterých se omezující rozsudek opatrovnického soudu netýká. Je také možné, že bude osobě navrhovatele omezena svéprávnost až v průběhu řízení. Pak by soud musel jednat s navrhovatelem pouze v rozsahu, ve kterém není jeho svéprávnost omezena ${ }^{26}$, ve zbytku pak s opatrovníkem navrhovatele.

Zvláštní úprava účastenství v řízení o umoření listiny se nachází v ustanovení \305 odst. 1 věty druhé ZŘS, podle něhož , „n]âurh na umořni listiny mư̌̌e podat každý, kedo má na jejím umoreni právni zájem. " Pod tuto zákonnou definici bude ve většině ${ }^{27}$ př́padů možné podřadit vlastníka ztracené, zničené nebo odcizené listiny. Jsme toho názoru, že není pochyb o vlastníkově právním zájmu na amortizaci listiny, kterou z nejrůznějších důvodů nemůže využít k uplatnění v ní inkorporovaných práv. Zatímco názor, že vlastník listiny může být navrhovatelem v řízení o její amortizaci, je nekontroverzní, názory, zda může být navrhovatelem ještě jiná osoba, se již poměrně liší. Podle nás má právo podat návrh na umoření dané listiny i oprávněný držitel, tj. osoba, jež listinu měla v držbě ve smyslu

24 JIRSA, Jaromír. \ 103. In: JIRSA, Jaromír, Vladimír BERAN a kol. Občanské soudní rízení. Soudcovský komentár. Kniba II (』 79 až』 180 o. s. r.). 3. vyd. Praha: Wolters Kluwer Česká republika, 2019, 648 s.; nebo PŘIDAL, Ondřej. \103 [Podmínky řízení]. In: SVOBODA, Karel, Petr SMOLÍK, Jiří LEVÝ a Renáta ŠíNOVÁ. Občanský soudní rád. 2. vyd. Praha: Nakladatelství C. H. Beck, 2017, s. 435.

25 Upozorňujeme, že žádnou osobu nelze omezit ve svéprávnosti tak, že mj. nemá přístup k soudům a jiným orgánům veřejné moci. K tomu srov. nález Ústavního soudu ze dne 7. 12. 2005, sp. zn. IV. ÚS 412/04, nebo rozsudek Evropského soudu pro lidská práva ze dne 13. 10. 2009, ve věci Salontaji-Drobnjak proti Srbsku.

26 Tedy v rozsahu, ve kterém má navrhovatel procesní způsobilost dle $\int 20$ OSŘ.

27 Př́kladem výjimky je situace, kdy je listina zástavou. $V$ takovém př́padě je $\mathrm{k}$ podání návrhu na umoření zastavené listiny oprávněný zástavní věřitel, nikoli však už vlastník listiny, tedy zástavní dlužník. $\mathrm{K}$ tomu srov. usnesení Nejvyššího soudu ze dne 30. 10. 2007, sp. zn. 21 Cdo 2748/2006, ve kterém se uvádí, že „navrhovatel, keterý predmètné akcie předal zástavní véritelce [...] a keterému nebyly do podání návrbu vráceny, není vèné legitimován k.jejich umoření, $i$ kdyby byly skutečnè ztraceny nebo zničeny. " 
ustanovení $\ 987 \mathrm{OZ}$, ale z nějakého důvodu nad touto listinou pozbyla fyzickou kontrolu. Vycházíme jak z gramatického výkladu podmínky, že návrh na umoření listiny může podat „každý, kedo má na jejim umorení právni zájem", tak i v některých situacích z praktické potřeby, aby bylo oprávněnému držiteli umožněno podat návrh iniciující zahájení rízení o amortizaci listiny. Navrhovatelem tak může být nap̌r. zástupce vlastníka listiny, která má být umořena. Důvodem, který nás $\mathrm{k}$ tomuto závěru vede, je projev svobodné vůle vlastníka listiny nakládat $\mathrm{s}$ touto listinou dle jeho uvážení. ${ }^{28}$ Pokud totiž např. vlastník listinné akcie udělí plnou moc jiné osobě $\mathrm{k}$ tomu, aby jej zastupovala na valné hromadě dané akciové společnosti a aby uplatňovala práva inkorporovaná do jeho akcie, a tento zástupce by listinnou akcii např. ztratil, měl by mít možnost iniciovat její umoření. Uvedené však platí pouze tehdy, pokud by podání návrhu nemohl bez zbytečného odkladu ${ }^{29}$ provést sám vlastník listiny.

S tímto argumentem souvisí i otázka, zda může navrhovatelem být nap̌r. uschovatel listiny, ${ }^{30}$ kterou má u sebe uschovanou na základě smlouvy o úschově. Odpověd' není jednoznačná; v odborné literatuře lze nalézt názory pro i proti. ${ }^{31}$ Pro kladnou odpověd’ svědčí, že nebude-li z důvodu svého (patrně jen) nedbalostního ${ }^{32}$ jednání uschovatel schopen dostát svému závazku vyplývajícího ze smlouvy o úschově, bude vhodné a žádoucí, aby právě uschovatel byl oprávněn podat návrh. $Z$ porušení svého závazku by mu totiž hrozila sankce vyplývající z dané smlouvy, príp. též ze zákona, a neměla by mu být kladena překážka. ${ }^{33}$ Navíc by bylo i zcela nepraktické, pokud by musel uschovatel (nebo jiný oprávněný držitel) umořované listiny kontaktovat vlastníka listiny, ${ }^{34}$ aby tento podal návrh $\mathrm{k}$ soudu, př́padně aby vlastník udělil držiteli plnou moc $\mathrm{k}$ oprávnění podat návrh na umoření listiny. Problematické by to bylo zejména $\mathrm{v}$ situacích, kdy by vlastník listiny (schovatel) byl dlouhodobě v zahraničí. Bylo by nevhodné, aby se zahájení rízení a účinky s tímto okamžikem spojené projevily až s časovým odstupem od okamžiku, kdy se o skutečnosti zakládající umořitelnost listiny vlastník dozvěděl. $\mathrm{V}$ tomto mezičase by totiž, $\mathrm{v}$ prípadě odcizení listiny, mohlo být uplatněno s listinou spojené právo

28 Toto právo je zakotveno mj. v čl. 11 ústavního zákona č. 23/1991 Sb., kterým se uvozuje Listina základních práv a svobod.

29 Byl by např. na zahraniční pracovní cestě, žil by dlouhodobě v zahraničí atp., přičemž tyto skutečnosti by mu prakticky znemožnily podat návrh na umoření včas.

30 LEVÝ, Jiří. Díl 2. Řízení o umoření listiny. In: SVOBODA, Karel, Šárka TLÁŠKOVÁ a kol. Zákon o zulástnich rízenich soudních. Komentár. 1. vyd. Praha: C. H. Beck, 2015, s. 587.

31 Srov. citace dále v textu. Pro dokreslení rozporuplnosti přístupơ k této problematice uvádíme, že oba autoři na ni zastávají opačný názor.

32 Je zde oprávněný předpoklad, že v případě úmyslného jednání, jehož výsledkem by bylo zničení nebo odcizení listiny, by uschovatel nepodal návrh na umoření zničené nebo odcizené listiny.

33 V podobě restriktivního výkladu ustanovení \ 305 odst. 1 ZŘS.

34 Tím však rozhodně nemyslíme, aby oprávněný držitel listiny zpo̊sobilé k umoření nekontaktoval vlastníka listiny vůbec. Ostatně vlastník by se o umořování své listiny dozvěděl nejpozději na základě ediktu. 
neoprávněnou osobou. ${ }^{35}$ Opačný názor, tedy že by navrhovatelem byl i př́padný schovatel listiny, má Karel Svoboda, který výslovně uvádí, že „,[n]elze prïpustit, aby uschovatel sám činil kroky k. zaplacení nebo uchování práva na plnèné plnèni uvedenébo v listinè, kterou mèl v úschovè, protože takové konánípř̌sluši jedinè schovateli jako prímému věriteli. "36 Negativní odpovědi svědčí i obecné pravidlo, že navrhovatelem je osoba, která je z umořované listiny oprávněná. Uvedené souvisí také s identifikací účastníků v meritorním usnesení, jímž je listina umořena. Osoba oprávněná vykonávat práva inkorporovaná do umořené listiny bývá v usnesení označena jako navrhovatel. Variantě, že by uschovatel podal návrh na umoření listiny z nekalých pohnutek, nepřikládáme praktický význam, nebot’ by mělo být vždy zajištěno, aby se vlastník listiny o zahájeném řízení o amortizaci své listiny dozvěděl (nejpozději na základě ediktu). Pokud by tak uschovatel byl v pozici navrhovatele, mohlo by dojít k nezamýšleným důsledkům a soud by usnesením mohl de facto legitimizovat nežádoucí a protiprávní stav, kdy by se uschovatel listiny jako navrhovatel jejího umoření stal (jedinou) ${ }^{37}$ osobou oprávněnou požadovat plnění z listiny. Soudy poprvé rozhodující o tom, zda může umoření listiny navrhnout její uschovatel, tak budou muset zvážit, zda výhody tohoto př́stupu (možnost uschovatele napravit své prrípadné pochybení, jež vedlo ke zničení či ztrátě listiny) převáží jeho nevýhody (uschovatel se může stát jedinou osobou oprávněnou požadovat plnění z výsledného usnesenî).

Posledním myslitelným navrhovatelem by mohla být osoba z listiny povinná. V tomto př́padě by se podaným návrhem povinná osoba bránila tomu, aby prrípadně nebyla nucena plnit někomu neoprávněnému. Zároveň (byt’ by to pravděpodobně nebyl její primární záměr) by tímto svým jednáním chránila též oprávněného vlastníka listiny navržené k umoření. Jsme si však vědomi i toho, že by podaným návrhem na umoření listiny mohla povinná osoba sledovat vlastní cíl, aby např. oddálila výplatu dividendy v př́padě akcie.

Zejména u dlužníka z listiny je tak nutné, aby soud bedlivě zkoumal právní zájem navrhovatele na amortizaci dané listiny. Navrhne-li dlužník z listiny její umoření, soud by měl nejdřive oslovit osobu z listiny oprávněnou, kterou by ve většině případů měl být právě její držitel. Tím by totiž docílil toho, že se o umořovacím řízení dozví, a také, že soud bude schopen velmi rychle zjistit, zda je návrh důvodný. Námitkou proti navrhovanému postupu by mohla být skutečnost, že oznamovací funkci plní soudem vydaný edikt, na jehož základě se o řízení o umoření listiny její vlastník, či oprávněný držitel dozví a může se proti návrhu bránit námitkami, příp. prostřednictvím přihlášky do řízení vstoupit za současného předložení listiny, která má být umořena. Tento postup je však velmi

35 Toto riziko se netýká listin s formou na řad, nebot’ by neoprávněný držitel nemohl dokázat, že listina patří jemu, nebot’ by neměl k předložení listiny a požadování plnění žádný právní důvod.

36 SVOBODA, Karel. Otazníky v řízení o umoření listiny. Jurisprudence, Praha: Wolters Kluwer Česká republika, 2014, č. 6, s. 40-44.

37 Viz níže $\mathrm{k}$ dopadům formy usnesení o umoření listiny. 
formalistický, nebot' oprávněný držitel se ani nemusí dozvědět, že byl edikt vydán, a tedy že bylo zahájeno řízení o umoření listiny, kterou u sebe má. V př́ípadě, že by amortizaci navrhl dlužník z listiny, by měla být první fáze rrízení pojímána materiálně a funkčně, tedy tak, aby soud zjistil, nikoli formálními prostředky, skutečnou vưli vlastníka, či oprávněného držitele umořované listiny. Pokud soud nazná, že navrhovatelem je osoba, která nemá na umoření listiny právní zájem, návrh bez dalšího zamítne. ${ }^{38}$

Shrňme tedy, že účastníkem řízení bude vždy (1) osoba, která podá návrh na umoření dané listiny, (2) osoba, která je z listiny povinna plnit, (3) osoba, která má umořovanou listinu v držbě a prrihlásí ji do řízení, př́íp. (4) kdokoli, kdo podá námitky na základě vydaného ediktu (viz níže). ${ }^{39}$ Připomínáme, že všechny tyto typy účastníků se nemusí $\mathrm{v}$ daném rrízení vyskytnout vůbec (např. nedojde-li k podání námitky) a jedna osoba může spadat zároveň do více kategorií (např. osoba z listiny zavázaná mưže mít listinu zároveň i v držbě a př́ihlásit ji do řízenî).

\section{Neobvyklý procesní subjekt?}

Existuje další subjekt, který může v každém řízení o umoření listiny vystupovat. Do amortizačního řízení může vstoupit i př́slušné okresní (obvodnî) státní zastupitelství. O řízení se dozví na základě upozornění okresního (obvodního) soudu, u něhož byl podán návrh na umoření listiny. ${ }^{40}$ Pokud státní zastupitelství soudu oznámí, ${ }^{41}$ že do umořovacího řízení vstupuje, stává se tímto okamžikem dalším procesním subjektem amortizačního řízení. Jiří Levý uvádí, že je postavení státního zastupitelství v rovině zvláštního procesního subjektu, nikoli účastníka řízení. ${ }^{42}$ Má však všechna práva a povinnosti účastníků řízení s výjimkou procesních úkonů, které může vykonat výlučně účastník řízení. ${ }^{43}$ Státní zastupitelství tedy nap̌r. nemůže vzít návrh zpět, což lze dovodit i z ustanovení \8

38 SEDLÁK, Viktor a Alena NOVOTNÁ. \305 Zahájení rúzení. In: JIRSA, Jaromír, Daniela KOVÁŘOVÁ a kol. Občanské soudní rǐzení. Soudcovský komentár. Kniba III. Zvlástní rǐzení soudní. 3. vyd. Praha: Wolters Kluwer Česká republika, 2019, 1136 s.

39 LEVÝ, Jiř́. Díl 2. Rízení o umoření listin. In: SVOBODA, Karel, Šárka TLÁŠKOVÁ a kol. Zákon o zulástnich řzzeních soudnich. Komentár. 1. vyd. Praha: Nakladatelství C. H. Beck, 2015, s. 590-591; nebo také CHALUPA, Radim. Díl 2. Řizení o umoření listin. In: LAVICKÝ, Petr a kol. Zákon o zulástních ř̌zeniéch soudnich. Řizení nesporné. Praktický komentár. Praha: Wolters Kluwer Česká republika, 2015, s. 561.

$40 \mathrm{~K}$ tomu srov. ustanovení $\ 4$ odst. 1 písm. h) zákona č. 283/1993 Sb., o státním zastupitelství, ve znění pozdějéśích předpisů, ve spojení $s \rrbracket 8$ odst. 1 písm. h) Ž̌S.

41 Jsme toho názoru, že státní zastupitelství může do ř́zení vstoupit po předchozí výzvě soudu, nebo i bez takové výzvy, tedy dozví-li se o takovém řízení ze své činnosti. Pravděpodobnější patrně bude první varianta.

42 LEVÝ, Jiří. Díl 2. Řízení o umoření listin. In: SVOBODA, Karel, Šárka TLÁŠKOVÁ a kol. Zákon o zulástnich ř́zenich soudnich. Komentár. 1. vyd. Praha: C. H. Beck, 2015, s. 591. Tento názor byl podpořen i judikaturou Nejvyššího soudu. K tomu srov. např. usnesení Nejvyššího soudu ze dne 24. 2. 2015, sp. zn. 21 Cdo 819/2014.

$43 \mathrm{~K}$ tomu srov. ustanovení $₫ 35$ odst. 2 OSŘ. 
odst. 2 ZŘS a contrario, nebot' státní zastupitelství v tomto případě není v pozici navrhovatele. $\mathrm{Na}$ druhou stranu státnímu zastupitelství z jeho pozice v umořovacím řízení svědčí např. právo podat odvolání, vstoupilo-li do řízení dříve, než uplynula lhưta pro podání odvolání pro účastníky řízení. ${ }^{44}$

Státní zastupitelství může do řízení, která jsou taxativně uvedena v $\int 8$ odst. 1 ZŘS, vstoupit ,jen výjimečně, aby häjilo verejné (státní) zájmy. ${ }^{45}$ stup státního zastupitelstvi do rízeni ovšem neni vázán na podminku, že se jej takové rízeníjakýmkoliv zpiosobem prímo dotýká. " $\mathrm{Z}$ Z uvedeného vyplývá, že státní zastupitelství vykonává určitou formu dozoru, nebot’ zde existuje veřejný zájem patrně zejména na výsledném upravení právních vztahů vyplývajících z umořené listiny. Dalším důvodem může být též dohlížení nad tím, aby v průběhu ř́zení o umoření dané listiny nedošlo k pozměnění jejího obsahu, resp. aby po vydání meritorního usnesení o umoření dané listiny nedošlo k pozměnění v návrhu uvedené listiny za listinu jinou. Lze si tedy představit i krajní situaci, kdy amortizační řízení může potenciálně zavdat př́činu pro zahájení trestního řízení.

\section{Listiny soudem umořitelné}

Vedle okruhu účastníků je další podmínkou řízení o umoření listiny, aby byla listina, jejíž amortizace se navrhuje, umořitelná. Zákon stanovuje pro umořitelnost listin dvě kumulativní podmínky. Zaprvé se musí jednat o listinu zničenou ${ }^{47}$ nebo ztracenou. ${ }^{48} \mathrm{Za}$ ztracenou listinu lze považovat rovněž listinu odcizenou, avšak pouze za předpokladu, že vlastník listiny pachatele nezná a neví, kde se listina nachází. ${ }^{49} \mathrm{Je}$-li odcizitel listiny jejímu vlastníkovi znám, může se po něm domáhat vydání listiny reivindikační žalobou. V úvahu připadá rovněž povinnost nahradit škodu vzniklou odcizením listiny (např. pokud by tím bylo vlastníku znemožněno vykonání zachovávacích úkonů ke směnce). Zničení listiny

44 LEVÝ, Jiří. \8 [Oprávnění státního zastupitelství]. In: SVOBODA, Karel, Šárka TLÁŠKOVÁ a kol. Zákon o zuláśtních ř́zeních soudních. 1. vyd. Praha: Nakladatelství C. H. Beck, 2015, s. 1-2.

$45 \mathrm{~V}$ praxi však státní zastupitelství je zvláštním procesním subjektem téměř každého řízení o umoření listin, a to z vlastní iniciativy. Odpovědí na otázku, proč tomu tak je, může být, že je v zájmu státního zastupitelství dohlédnout na zákonnost návrhu i celého řízení. Účast státního zastupitelství může mít pro řízení příznivý vliv na případné „,podvodné“ navrhovatele. Psychologický efekt účasti státního zastupitelství v ř́zení o umoření listin však nelze nijak dokázat.

46 K tomu srov. usnesení Nejvyššího soudu ze dne 29. 6. 2006, sp. zn. 29 Odo 44/2004, citovaného v JIRSA, Jaromír. \8 Oprávnění státního zastupitelství. In: JIRSA, Jaromír, Daniela KOVÁŘOVÁ a kol. Občanské soudni rízení. Soudcovský komentár. Kniha III. Zvláštni rízeni soudní. 3. vyd. Praha: Wolters Kluwer Česká republika, 2019, 1136 s.

47 Vždy se jedná o fyzické zničení listiny, nikoli právní. K tomu srov. DVOŘÁKOVÁ, Zuzana. Umoření blankosměnky. Obchodněprávní revue, 2018, roč. 10, č. 9, s. 253-259.

48 Jedná se o situaci, kdy oprávněná osoba nemůže s listinou z objektivních důvodů disponovat, a navíc, když není zřejmé, kde se listina nachází. Srov. SVOBODA, Karel. 2. Předmět řízení. In: SVOBODA, Karel. Nesporná ř́zení I. 1. vyd. Praha: Nakladatelství C. H. Beck, 2015, s. 245.

49 K tomu srov. rozhodnutí Nejvyššího soudu ze dne 26. 9. 2012, sp. zn. 21 Cdo 4379/2011. 
nemusí spočívat pouze $\mathrm{v}$ celkové likvidaci podkladu (např. shořením či skartacî), stačí, aby došlo ke zničení či ke znečitelnění podstatných (pro uplatnění práva relevantních či nezbytných) prvků listiny. ${ }^{50}$

Druhou podmínkou umořitelnosti listiny je, aby s ní bylo určité právo tak spjaté, že by jej bez předložení listiny nebylo možné uplatnit. ${ }^{51}$ Tato definice se podobá definici cenných papírů. Všechny listiny naplňující definiční znaky cenných papírů obsažené v \514 OZ tak budou tuto podmínku splňovat. Okruh umořitelných listin je však širší. $\mathrm{K}$ založení umořitelnosti nemusí být právo v listině prrímo inkorporováno, nýbrž stačí, aby listina byla nezbytná $\mathrm{k}$ jeho uplatnění a prípadnému nárokování. ${ }^{52}$ Judikatorně potvrzeným príkladem umořitelné listiny, která není cenným papírem, je listina obsahující prohlášení vkladatele o vložení nemovitosti do základního kapitálu obchodní korporace. ${ }^{53}$ Zmiňovanou podmínku však nesplní listiny, jež lze nahradit jejich opisem. ${ }^{54}$

Dané zákonné ustanovení pokračuje v negativním výčtu listin, které umořit nelze. V první skupině jsou listiny vystavené právnickou osobou, které listinu vystavila a je ze zákona oprávněna ji také umořit. Je však otázkou, které listiny je možné pod ustanovení $\ 304$ odst. 2 ZǨS vůbec podřadit. Do 31. 12. 2013 se dle ustanovení \185i odst. 2 OŠ̌ nedaly umořit listiny, které mohla umořit právnická osoba, která danou listinu vydala. Doslovné př́ijetí $\ 185 i$ odst. 2 OSŘ do dnešního $\ 304$ odst. 2 Ž̌S se nám však jeví nekoncepční. Zákonodárce totiž nezohlednil skutečnost, že $\mathrm{v}$ hmotněprávní úpravě naopak učinil změny. Ty spočívají např. v tom, že do 31. 12. 2013 bylo možné, aby ztracenou, zničenou či odcizenou vkladní knížku umořila banka, která byla jejím vydavatelem. V rekodifikované právní úpravě, konkrétně v $\ 2678$ OZ, zákonodárce vydavateli vkladní knížky umožňuje při její ztrátě nebo zničení, aby na žádost majitele vystavil vkladní knížku novou. O umoření té ztracené se však již zákonodárce nezmiňuje. Chybî zde tedy jakýsi první krok spočívající v umoření ztracené nebo zničené vkladní knížky. Výkladem ${ }^{55}$ by však bylo možné dospět k závěru, že účinky vydání nové vkladní knížky jsou obdobné jako u vydání usnesení o umoření listiny soudem, nebot' ani v př́padě, že by ztracenou (zničenou asi nikoli) vkladní knížku našla osoba odlišná od majitele, by ji tato osoba nemohla úspěšně uplatnit ${ }^{56}$ protože ,tato [nová] vkladni knižka nabrazuje

50 Za zničenou byla považována např. směnka, $\mathrm{k}$ jejímuž vyplnění i podpisu použil výstavce neviditelný inkoust, který po určité době beze stopy zmizel (viz rozsudek Krajského soudu v Ostravě ze dne 24. 9. 2015, č. j. $27 \mathrm{Cm} \mathrm{89/2015-47).}$

51 Srov. ustanovení $₫ 304$ odst. 1 ZŘS.

52 SVOBODA, Karel. Nesporná rízení I. Praha: C. H. Beck, 2015, s. 242.

53 Viz usnesení Krajského soudu v Brně ze dne 5. 9. 2003, sp. zn. 18 Co 44/2003 (uveřejněné pod číslem 6/2004 Sbírky soudních rozhodnutí a stanovisek).

54 DVOŘÁKOVÁ, Zuzana. Umoření blankosměnky. Obchodněprávní revue, 2018, roč. 10, č. 9, s. 253-259.

55 PLACZEK, Ondřej. Umoření cenných papirui. Diplomová práce. Brno: Masarykova univerzita, Právnická fakulta, 2019, s. 1-65.

56 Pochopitelně za předpokladu, že již bude vydána vkladní knížka nová. 
pưvodní veladni knǐ̌̌ku, keterá pozbývá dnem jejiho vystaveni platnosti. "57 Mezi listiny, na něž se vztahuje ustanovení $\ 304$ odst. 2 ZŘS, je podle našeho názoru dále nutno zařadit náložné listy (konosamenty), které jejich výstavce (dopravce) nahrazuje sám v režimu \2574 OZ. Ani náhradu konosamentů však OZ výslovně neoznačuje jako "umoření". $\mathrm{V}$ prípadě obou zmíněných listin tak lze polemizovat, zda je zákonodárce $\mathrm{z}$ režimu $\ 304$ odst. 2 ZŘS vědomě vyloučil a umožnil tak jejich vlastníkovi (v prŕpadě jejich ztráty či zničenî) možnost opce preferovaného způsobu náhrady. Výhodu nastíněného výkladu si lze ilustrovat např. na situaci, kdy výstavce zničeného náložného listu zanikne. Umoření konosamentu soudem podle úpravy obsažené $\mathrm{v}$ ZǨS by tak jeho vlastníku umožnilo uplatnit např. právo proti nepř́ímému dlužníku. Pokud bychom se však ke zmiňovanému výkladu přiklonili, ustanovení $\ 304$ odst. 2 ZŘS by upravovalo prázdnou množinu listin.

Druhou skupinou jsou zákonodárcem konkrétně vypočtené listiny, které nelze umořit ani vydavatelem listiny, ani soudem. Alena Novotná s Viktorem Sedlákem jsou přesvědčeni, že je výčet demonstrativní, ačkoli takto jasně zákonodárce ustanovení nestanovil. ${ }^{58}$ K tomuto závěru se prìklání též Radim Chalupa, který jako př́klad neumořitelné listiny uvádí listiny důkazní, ${ }^{59}$ které by bylo možné nahradit jiným důkazem. ${ }^{60} \mathrm{~K}$ neumořitelnosti důkazních listin lze doplnit, že by jejich umoření ani nemělo smysl, nebot' na konci řízení o umoření listin není vydána jakási identická kopie, nýbrž usnesení, z něhož není možné dovodit původní „originál“ důkazní listiny. Pokud by byl podán návrh na umoření neumořitelné listiny, soud usnesením návrh bez dalšího zamítne. ${ }^{61}$ Při výčtu neumoritelných listin považujeme za nutné upozornit na nekoncepční pochybení zákonodárce, který takto vyloučil umořitelnost kupónu. ${ }^{62}$ Kupón je vedlejším cenným papírem inkorporujícím právo na výnos z cenného papíru hlavního, ${ }^{63}$ jehož umoření ustanovením \ 304 odst. 3 ZŘS znemožněno. Znění ZŘS je v tomto ohledu zjevně inspirováno ustanovením \2 odst. 2 písm. c) již zmiňovaného zákona o umořování listin. Považujeme však za politováníhodné, že zákonodárce z tohoto zákona nepřevzal rovněž ustanovení $\ 19$, které umožňovalo vlastníku zničeného či ztraceného kupónu (po splnění

57 Srov. ustanovení \2678 větu druhou OZ.

58 SEDLÁK, Viktor a Alena NOVOTNÁ. \ 304 Předmět řízení. In: JIRSA, Jaromír, Daniela KOVÁŘOVÁ a kol. Občanské soudní ř̌zení. Soudcovský komentár. Kniba III. Zvlástní rižení soudní. 3. vyd. Praha: Wolters Kluwer Česká republika, 2019, $1136 \mathrm{~s}$.

59 K tomu srov. ustanovení $₫ 115$ vyhlášky Ministerstva spravedlnosti ČR č. 37/1992 sb., o jednacím řádu pro okresní a krajské soudy, ve znění pozdějších předpisů.

60 CHALUPA, Radim. Díl 2 Řízení o umoření listin. In: LAVICKÝ, Petr a kol. Zákon o zuláštních rízeních soudních. Řizení nesporné. Praktický komentár. Praha: Wolters Kluwer Česká republika, 2015, s. 553-554 a tam uvedené rozhodnutí Krajského soudu v Ústí nad Labem, sp. zn. 29 Co 190/2005.

61 SEDLÁK, Viktor a Alena NOVOTNÁ. S 304 Předmět řízení. In: JIRSA, Jaromír, Daniela KOVÁŘovÁ a kol. Občanské soudni řžení. Soudcovský komentár. Kniba III. Zvlästní rözení soudní. 3. vyd. Praha: Wolters Kluwer Česká republika, 2019, 1136 s.

62 Srov. ustanovení \ 304 odst. 3 ZǨS.

63 Srov. ustanovení $₫ 523$ OZ. 
předepsaných podmínek) domáhat se po jeho výstavci plnění. Dojde-li dnes ke ztrátě či zničení kupónu, platná úprava nenabízí jeho vlastníku žádnou cestu efektivní nápravy, nebot' kromě umoření (jež v důsledku ustanovení \ 304 odst. 3 ZŘS nepřichází v úvahu) neexistuje zákonná úprava pro náhradu cenných papírů.

Ustanovení \304 odst. 3 ZŘS tak prrímo volá po novelizaci. Než k ní však dojde, výstavci cenných papírů s kupóny by si měli být popsané mezery v zákoně vědomi a je-li to možné, předem se na ni připravit. Lze tak doporučit, aby s možností ztráty či zničení kupónů počítaly již např. emisní podmínky dluhopisů a nepojmenovaných cenných papírů či stanovy akciových společností. Tyto dokumenty mohou ex ante stanovit pravidla, jimiž se emitent kupónu bude v př́padě jeho ztráty či zničení řídit a kterými si jeho nešt’astný vlastník bude moci zajistit spolehlivý způsob nápravy.

\section{Edikt a další průběh řízení}

Pokud návrh na umoření listiny obsahuje všechny náležitosti předepsané zákonem, ${ }^{64}$ navrhovatel zaplatil soudní poplatek ve výši $1000 \mathrm{Kč},{ }^{65}$ soud vydá výzvu k předložení listiny (edikt), ${ }^{66}$ kterou doručí všem účastníkům a osobám, které by dle soudu pro svůj vztah k věci mohly věc objasnit. ${ }^{67}$ Edikt se rovněž vyvěšuje na úřední desku soudu. Počínaje vyhlášením tohoto usnesení začíná také běžet tzv. ediktní lhůta. ${ }^{68}$ Jejím hlavním účelem je umožnit osobám, jejichž práva by mohla být neoprávněným umořením listiny zasažena, bránit se proti umoření.

V tomto ohledu zákon rozeznává přihlášku listiny a námitky proti umoření. Přihlásí-li listinu její držitel do řízení, dokáže tím, že tato nebyla ztracena či zničena a není tak splněna jedna z podmínek řízení. $V$ tom př́ípadě soud návrh na její umoření zamítne. Institut námitek (navzdory zavádějící formulaci \307 odst. 1 ZŘS) oproti tomu slouží osobám, které listinu nedrží, avšak nesouhlasí s navrhovaným umořením (např. proto, že listina nikdy nevznikla, nebo sice vznikla, ale s jiným obsahem). Uplatnění námitek nevede $\mathrm{k}$ automatickému zamítnutí návrhu. Soud se však musí s námitkami vypořádat, k čemuž provede dokazování. Právě pro vypořádání námitek platí, že se naplno projevují prvky sporné povahy amortizačního řízení, nebot’ navrhovatel a ten, kdo námitky uplatnil, zastávají kontradiktorní postavení. Pokud soud dospěje k závěru, že námitky byly

64 Ustanovení \ 42 odst. 4 OSŘ, \ 79 odst. 1 OŠ̌ a \ 305 odst. 2 ZŘS.

65 Podle položky 15 př́lohy k zákonu č. 549/1991 Sb., o soudních poplatcích, ve znění pozdějších předpisů.

66 Ustanovení \307 odst. 1 Ž̌S.

67 Ustanovení $\int 116$ odst. 2 vyhlášky Ministerstva spravedlnosti č. 37/1992 Sb., o jednacím řádu pro okresní a krajské soudy, ve znění pozdějších předpisů.

68 Délka ediktní lhůty je obecně 1 rok. V případě umoření směnek či šekủ je lhůta zkrácena na 2 měsíce od prvního dne jejich splatnosti (popř. od vyhlášení ediktu, pokud již listina splatná je). Ediktní lhůta pro listiny na doručitele je rovněž modifikována: skončí 1 rok po splatnosti pohledávky z listiny (srov. \307 odst. 2-4 Ž̌s). 
uplatněny důvodně, návrh na umoření listiny zamítne. Je důležité upozornit na rozhodnutí Nejvyššího soudu ze dne 28. 2. 2017, sp. zn. 29 Cdo 571/2015, dle něhož jsou soudy povinny zohlednit i ty přihlášky či námitky, které byly uplatněny po uplynutí ediktní lhůty, avšak před vydáním rozhodnutí, jímž se řízení končí. Pokud by došlo k uplatnění námitky či přihlášky až po datu rozhodnutí ve věci samé, v úvahu přichází posuzovat takové podání v souladu s \41 odst. 2 OSŘ jako odvolání. Vzhledem k zásadě neúplné apelace, jîž je amortizační řízení ovládáno, by však v tomto př́ípadě nebylo možno uplatnit nové skutečnosti (s výjimkou případů uvedených v \205a OSŘ).

Nedošlo-li k zamítnutí návrhu, po uplynutí ediktní lhůty počíná běžet nová, měsíční lhůta, po kterou může navrhovatel podat opětovný návrh na umoření listiny. Neučiní-li tak, soud řízení zastaví; v opačném prrípadě soud rozhodne o umoření listiny usnesením.

Požadavek podání opětovného návrhu na umoření je podle nás neodůvodněný a nadbytečný, nebot' navrhovatel svůj zájem na umoření listiny dostatečně osvědčuje již samotnou iniciací amortizačního řízení. ${ }^{69}$ Nutnost potvrdit jej podáním opětovného návrhu je přitom v rozporu se zásadou postupu soudu z úřední povinnosti.

Aktuální koncepci tak považujeme za zbytečně přísnou a sloužící pouze jako „chyták“ pro nepozorného navrhovatele. Do jejího př́padného odstranění novelizací je však (vzhledem k poměrně krátké lhưtě a tvrdému postihu ${ }^{70}$ za nepodání) důležité, aby navrhovatelé zůstali i po „úspěšném“ uplynutí ediktní lhưty obežretní.

\section{7 Účinky usnesení o umoření listiny}

Pravomocné usnesení, jímž byla listina prohlášena za umořenou, tuto listinu nahrazuje, a to do chvíle, než dojde $\mathrm{k}$ vystavení náhradní listiny. ${ }^{71}$ To znamená, že právo původně inkorporované $v$ umořené listině je $z$ této listiny odňato (tzv. účinek zrušující či kasatornî) ${ }^{72}$ a přechází do usnesení o jejím umoření (tzv. účinek nahrazujícî) a k jeho uplatnění je nutno předložit stejnopis tohoto rozhodnutí. Pokud byla umořovaná listina cenným papírem, stává se cenným papírem i usnesení o jejím umoření. Popsanou koncepci, kdy je právo inkorporováno v soudním rozhodnutí, však považujeme za velice nešt'astnou, a to z následujících důvodů.

69 Právní řád navíc nezná jeho obdoby - jen stěží si lze představit, že by např. žalobce v běžném kontradiktorním řízení musel po skončení dokazování podat znovu žalobu.

70 Považujeme za vhodné upozornit, že usnesení o zastavení řízení o umoření je usnesení procesní povahy a nezakládá tak překážku věci pravomocně rozhodnuté ve smyslu ustanovení \159a odst. 4 OSŘ. Tato skutečnost poněkud tlumí následky zmeškání lhůty stanovené \ 313 odst. 3 ZŘS, nebot' navrhovatel může v „nejhorším případě“ zahájit nové řízení o umoření totožné listiny. To je však samozřejmě spojeno s novou poplatkovou povinností a s nutností opětovného uplynutí ediktní lhůty.

71 Ustanovení \ 315 Ž̌s.

72 CHALUPA, Radim. Díl 2 Rízení o umoření listin. In: LAVICKÝ, Petr a kol. Zákon o zuláštních ř́z̨eních soudních. Rizení nesporné. Praktický komentár. Praha: Wolters Kluwer Česká republika, 2015, s. 579. 
Zaprvé, může být obtížné identifikovat, se kterou fyzickou listinou je právo spojeno. ${ }^{73}$ Novým nosičem práva nemůže být originál usnesení, nebot' ten je založen do spisu. ${ }^{74}$ Právo z umořené listiny je tak spojeno se stejnopisem rozhodnutí, který je doručen navrhovateli. Další stejnopisy jsou ale doručeny i ostatním účastníkům ř́zení, ${ }^{75}$ aniž by byly formálně jakkoli odlišitelné od nové právonosné listiny. Praktickou uzancí je určení právonosného usnesení podle záhlaví rozhodnutí, v němž je původní navrhovatel označen; ${ }^{76}$ toto řešení je však podle nás pouhou z nouze ctností, s níž jsou spojeny další problémy. Např. v př́padě umoření cenných papírů je zjevně nežádoucí, aby bylo právonosné rozhodnutí (nahrazující cenný papír) identifikovatelné pouze skrze subjektivní prvek (osobu, která stejnopis rozhodnutí o usnesení předkládá).

Problematické je i převoditelnost usnesení o umoření listiny. Zdeněk Kovařík zastává názor, že usnesení o umoření listiny má účinky pouze inter partes a právo z amortizované listiny může uplatnit pouze navrhovatel. ${ }^{77}$ Kloníme se však spíše k názoru Zuzany Dvořákové, dle níž je nahrazovací účinek širší a neslouží pouze k legitimaci navrhovatele-věřitele uplatnit právo ze ztracené či zničené listiny. ${ }^{78}$ Má-li umořovací řízení poskytnout efektivní náhradu ztracené či zničené listiny, její případná převoditelnost musí být zachována i po umoření. Uznání převoditelnosti právonosného usnesení je však spojeno s praktickým problémem provedení samotného převodu. Byla-li umořována listina vydána ve formě na řad či na jméno, lze očekávat, že listina bude převoditelná podle $\int 1103$ odst. 2, resp. odst. 3 OZ, tzn. tradicí ve spojení s indosamentem, resp. cesí. Pokud je ovšem umořována listina na doručitele, prosté předání podle $\int 1103$ odst. $1 \mathrm{OZ}$ zřejmě nepostačí. Vzhledem k tomu, že právonosnou listinu lze identifikovat výlučně prostřednictvím osoby označené v jejím záhlaví, tradicí tuto listinu získává osoba třetí, jejíž jméno či název nelze ze stejnopisu usnesení nijak vyčíst a tato, byt' právonosná, listina se stává prakticky neodlišitelnou od ostatních stejnopisů doručených ostatním účastníkům. Nabyvatel právonosného usnesení tak bude jen s obtíží dokazovat, že zrovna jeho stejnopis je ten „pravý“. Provizorním řešením by mohl být „pseudoindosament “, tedy podpis, kterým by při prvním převodu navrhovatel označil právonosné usnesení a kterým by tak posílil důkazní situaci nabyvatele listiny snažícího se prokázat, že jde o listinu právonosnou.

73 Pro účely tohoto článku ji označíme za „právonosnou“.

74 Srov. ustanovení \ 14 odst. 1 instrukce Ministerstva spravedlnosti ze dne 3. 12. 2001, č. j. 505/2001-Org, kterou se vydává vnitřní a kancelářský řád pro okresní, krajské a vrchní soudy.

75 Ustanovení \ 314 ZǨS.

76 PLACZEK, Ondřej. Umořeni cenných papirio. Diplomová práce. Brno: Masarykova univerzita, Právnická fakulta, 2019, s 48.

77 KOVǍ̌íK, Zdeněk. In: MACKOVÁ, Alena a kol. Zákon o zuláštních rízeních soudních. Komentár s di̛vodovou zprávou a judikaturou. 1. vyd. Praha: Leges, 2016, s. 511.

78 DVOŘÁKOVÁ, Zuzana. Umoření blankosměnky. Obchodněprávní revue, 2018, roč. 10, č. 9, s 258. 
Z výše uvedeného jsou patrné nedostatky nahrazování umořené listiny soudním rozhodnutím. Za vhodnější proto považujeme, aby výstavce původní listiny vydal po její amortizaci oprávněnému listinu náhradní. Dojde-li k tomu, navrhovatel bude mít k dispozici skutečně plnohodnotnou náhradu za zničenou či ztracenou listinu. Co víc, vytratí se všechny praktické problémy a pochybnosti, které jsme právě popsali. S tímto řešením ostatně počítá i samotný ZŘS, když v \315 limituje nahrazovací účinek usnesení o umoření listiny právě vydáním listiny náhradní. Považujeme proto za velice nešt’astné, že zákonodárce neumožnil úspěšnému navrhovateli vydání náhradní listiny požadovat a prípadně se ho i soudně domoci, ${ }^{79}$ nebot' $\mathrm{v}$ př́padě dobrovolného nesplnění by bylo rozhodnutí o umoření listiny (jako jiná rozhodnutí směřující na plněnî) vykonatelné a emitent by byl k vystavení náhradní listiny nucen hrozbou sekundárních sankcí. V současné podobě je tak rozhodnutí, zda náhradní listinu vydat či ne, ponecháno pouze na dobré vưli emitenta, který může osobu z umořené listiny oprávněnou omezit např. právě v dispozici s usnesením

K nahrazujícímu účinku usnesení o umoření je rovněž nutno upozornit soudní praxi, dle níž „listinu lze umorit pouze v tépodobě, v jaké byla podle tvrzeni a popisu navrhovatele ztracena či zničena ... Zmèny, ke keterým došlo v prübèbu umořvacího řženi ... se nemohou projevit v označení listiny v usneseni dle $\int 185$ r odst. 1 o. s. r. ., k0 kerým se problašuje za umoŕenou. "81 Doplňujeme, že popis listiny v usnesení o jejím umoření by se měl rovněž zcela shodovat s popisem obsaženým v ediktu, nebot' jen tak je zajištěna právní jistota třetích osob. Jako „odstrašujíci“ př́lklad lze uvést postup Obvodního soudu pro Prahu 10 ve věci vedené pod sp. zn. 42 U 86/2015, který po vyhlášení usnesení o umoření směnky na základě žádosti navrhovatele (opravným usnesením) doplnil řadu indosamentů, které údajně pưvodní směnka obsahovala, aniž by tyto rubopisy byly zmiňovány v původním návrhu na umoření směnky či v ediktu. Případným třetím osobám, do jejichž práv mohlo být touto změnou zasaženo, tak nebylo umožněno bránit se proti umoření směnky.

\section{Závěr}

Ačkoli řízení o umoření listiny není přiliš častým soudním řízením, jeho důsledky jsou dalekosáhlé. Historicky nebylo amortizační řízení vyčleňováno z obecné úpravy civilních řízení, tedy z občanského soudního řádu. Ke změně došlo přijetím rekodifikované hmotněprávní právní úpravy, kdy 1. 1. 2014 zákonodárce řízení o umoření listiny

79 Obdobu námi navrhovaného institutu přitom obsahoval již zmiňovaný zákon o umořování listin (konkrétně šlo o jeho \17 odst. 2).

80 V aktuální právní úpravě se jedná o ustanovení \313 odst. 2 ZŘS.

81 Usnesení Městského soudu v Praze ze dne 20. 6. 2008, č. j. 24 Co 86/2008-48, uvedené v SEDLÁK, Viktor a Alena NOVOTNÁ. \304 Předmět řízení. In: JIRSA, Jaromír, Daniela KOVÁŘOVÁ a kol. Občanské soudni rízení. Soudcovský komentár. Kniha III. Zvláštni rízeni soudní. 3. vyd. Praha: Wolters Kluwer Česká republika, 2019, 1136 s. 
z občanského soudního řádu vyjmul a vložil jej do zákona o zvláštních rrízeních soudních. Nejednalo se však o pouhý jednoduchý krok přemístění právní úpravy. Charakter umořovacího rrízení je sice spíše nesporný, avšak v některých svých fázích je toto řízení silně ovlivňováno zásadami civilního řízení sporného. Př́kladem budiž uplatnění principu neúplné apelace nebo koncentrace řízení. Celé rúzení je pak ovládáno zásadou projednací, což bývá typické zejména pro civilní řízení sporná.

Obvykle není problematická otázka věcné a místní prríslušnosti soudu. Není žádných pochyb o tom, že návrh je projednáván okresním soudem jako soudem prvostupňovým. Z hlediska místní příslušnosti se můžeme setkat s několika pravidly. Základní pravidlo pro určení místní příslušnosti soudu však je dle \4 odst. 1 ve spojení s \303 odst. 1 ZŘS obecný soud navrhovatele určeného podle jeho bydliště. Výjimky jsou pak stanoveny pro situace, když je navrhovatelův obecný soud $\mathrm{v}$ zahraničí nebo když umořovanou listinu vystavila banka. Ve světle nejnovější judikatury Nejvyššího soudu je navíc upřesněno, že pravomoc českých soudů může být dána i v případě, že místně příslušný soud nelze zjistit podle pravidel $\int 303$ ZŘS.

Podmínkami amortizačního řízení jsou podání návrhu věcně a místně příslušnému soudu, a to osobou k tomu oprávněnou. Dále je nutné, aby v návrhu označenou listinu bylo právně možné umořit. S tím souvisí několik problémů. Jeden z nich spočívá v nejistotě, zda ustanovení \304 odst. 2 ZŘS i po rekodifikaci hmotněprávní úpravy dopadá na vkladní knížky a konosamenty, nebo zda se toto ustanovení stalo zcela obsolentní. Další problém spatřujeme v taxativním výčtu v \ 304 odst. 3 ZŘS, jímž jsou nekoncepčně z umořovacího řízení vyloučeny kupóny.

Po splnění základních i speciálních procesních podmínek je soudem vydán tzv. edikt, kterým soud dává na vědomí veřejnosti, že u něj probíhá řízení o návrhu na umoření konkrétní listiny. Soud v ediktu stanoví zákonem předvídanou lhůtu, ve které se soudu má přihlásit držitel listiny, anebo ve které může kdokoli vznést námitky proti umoření dané listiny. Po uplynutí ediktní lhůty však zákonodárce klade do cesty umoření listiny další překážku spočívající v požadavku, aby navrhovatel ve lhůtě 1 měsíce od uplynutí ediktní lhůty podal opětovný návrh na umoření této listiny. Toto zákonodárcem nevysvětlené opatření si vykládáme tak, že je povinností navrhovatele utvrdit soud, že jeho zájem na umoření umořované listiny trvá i nadále; v pořadí již druhý návrh nám však připadá nadbytečný a nedůvodný.

Pokud navrhovatel splní i tento požadavek, dospěje amortizační řízení svému konci a soud vydá usnesení o umoření listiny, které zcela přebírá účinky umořené listiny. Problémy však spatřujeme i v této fázi řízení. Vzhledem k tomu, že usnesení o umoření listiny je doručeno všem účastníkům řízení, vlastník usnesení, které nahrazuje umořenou listinu, je identifikovatelný pouze na základě obsahu záhlaví usnesení. Takový subjektivní prvek nepovažujeme za vhodný pro jinak velmi formální řízení. Další problém je potencialita omezení výkonu dispozičních práv s umořenou listinou, což je zřetelné zejména 
u převodu usnesení představující umořenou listinu ve formě na doručitele. Nevhodná je také skutečnost, že zákon nestanovuje povinnost emitenta původní listiny vystavit listinu novou. Soudem vydané usnesení nahrazující umořenou listinu tak nemusí být pouze dočasné, nýbrž trvalé. Domníváme se, že s popsanou koncepcí může být spojen i psychologický efekt spočívající v tom, že výsledné soudní usnesení působí o poznání „nuzněji“, než původní listina, zvláště pak jednalo-li se o cenný papír.

I pro tak ojedinělé rízení, jakým řízení o umoření listin je, lze proto shledat mnoho prostoru $\mathrm{k}$ nápravě. At’ už jde o vyjasnění okruhu osob oprávněných $\mathrm{k}$ navržení umoření listiny, umožnění umořit či jinak nahradit kupóny, anebo odstranění požadavku druhého návrhu po uplynutí ediktní lhůty, praxi by takové změny, dle našeho názoru, výrazně prospěly. Jelikož se v drtivé většině řízení účastní státní zastupitelství dohlížející na zákonnost ř́izení, domníváme se, že je namístě někdy př́lišnou tvrdost úpravy amortizace spíše zmírňovat. 